\title{
KOMUNIKASI PERSUASIF IKLAN LAYANAN MASYARAKAT DI TELEVISI TENTANG EDUKASI KANKER
}

\author{
Daniel Handoko ${ }^{1}$, Velda Ardia ${ }^{2}$, Oktaviana Purnamasari ${ }^{3}$ \\ Program Studi Ilmu Komunikasi FISIP Universitas Muhammadiyah Jakarta \\ E-mail : danielhandoko82@gmail.com¹, veldaardia@gmail.com², \\ oktavianapurnamasari@gmail.com ${ }^{3}$
}

\begin{abstract}
Cancer is the one of the highest killers in the world. In Indonesia, the prevalence of this disease is increasing from year to year. To reduce the number of cancer patients, the Ministry of Health has a variety of efforts, such as education to the public through Public Service Announcement (PSA) on television. PSA is needed primarily to mobilize the community to change behavior to a more positive direction as desired by the communicator. It takes proper persuasive communication so that the PSA can perform its function to influence people to change their behavior in a positive direction. This persuasive effort becomes interesting to be studied considering persuasive communication is related to various aspects, such as attitude, behavior and knowledge of target audience.

In the context of cancer education, persuasive communication is needed to convince people to be more concerned about cancer by implementing a healthy lifestyle so that cancer can be prevented. This study aims to find how persuasive communication in cancer education PSA could support behavior change in society. The research method used is case study using qualitative descriptive, trough data collection procedure of FGD (Focus Group Discussion).

The research was conducted in Cirendeu, Ciputat. Data survey was obtained from the students of the University of Muhammadiyah Jakarta who became informers. The data is analyzed qualitatively which is then interpreted and presented in the form of a description or narrative followed by conducted theoretical interpretation to give meaning to the result of the research that has been done.

Result of this study indicates that behavior of the target audience towards the PSA is quite positive. Some of informants like the storyline and animation aproach, but the weakness is the information in the PSAis less detailed. Information in persuasive communication of PSA seeks to change the pattern of community to be healthier where early examination or detection is needed as a form of prevention. Through PSA, public awareness of cancer can be increased to persuade people to be willing to prevent cancer.
\end{abstract}

Keywords: Persuasive Communication, Public Service Ads, Cancer Education

\begin{abstract}
ABSTRAK
Kanker adalah salah satu pembunuh tertinggi di dunia. Di Indonesia, prevalensi penyakit ini meningkat dari tahun ke tahun. Untuk mengurangi jumlah penderita kanker, Kementerian Kesehatan memiliki berbagai upaya, seperti edukasi ke masyarakat melalui Public Service Ads (ILM) di televisi. ILM sangat dibutuhkan terutama untuk memobilisasi masyarakat agar mengubah perilaku ke arah yang lebih positif seperti yang diinginkan oleh komunikator. Dibutuhkan komunikasi persuasif yang tepat sehingga ILM dapat menjalankan fungsinya untuk mempengaruhi orang untuk mengubah perilaku mereka ke arah yang positif. Upaya persuasif
\end{abstract}


ini menjadi menarik untuk dipelajari mengingat komunikasi persuasif terkait dengan berbagai aspek, seperti sikap, perilaku, dan pengetahuan khalayak sasaran.

Dalam konteks pendidikan kanker, komunikasi persuasif sangat dibutuhkan untuk meyakinkan masyarakat agar lebih peduli terhadap kanker dengan menerapkan gaya hidup sehat sehingga kanker bisa dicegah. Penelitian ini bertujuan untuk mengetahui bagaimana komunikasi persuasif dalam pendidikan kanker pada ILM dapat mendukung perubahan perilaku masyarakat.

Metode penelitian yang digunakan adalah studi kasus deskriptif kualitatif, melalui prosedur pengumpulan data dalam wawancara mendalam dan FGD. Penelitian dilakukan di Cirendeu, Ciputat. Survei data diperoleh dari mahasiswa Universitas Muhammadiyah Jakarta yang menjadi informan. Data dianalisis secara kualitatif yang kemudian ditafsirkan dan disajikan dalam bentuk deskripsi atau narasi diikuti dengan dilakukan penafsiran teoritis untuk memberi makna pada hasil penelitian yang telah dilakukan.

Dari analisis data penelitian diperoleh hasil bahwa perilaku khalayak sasaran terhadap ILM cukup positif, di mana beberapa informan menyukai alur cerita iklan dan pendekatan animasi yang digunakan dalam ILM edukasi kanker. Namun kelemahannya adalah informasi pada iklan ILM sering kali kurang detail. Informasi dalam komunikasi persuasif ILM berupaya untuk mengubah pola hidup masyarakat menjadi lebih sehat di mana pemeriksaan atau deteksi dini diperlukan sebagai bentuk pencegahan. Melalui ILM, kesadaran masyarakat akan kanker dapat ditingkatkan guna memersuasi masyarakat untuk bersedia melakukan pencegahan terhadap penyakit kanker.

\section{Kata kunci: Komunikasi Persuasif, Iklan Layanan Masyarakat, Edukasi Kanker, Perubahan Perilaku}

\section{PENDAHULUAN}

Iklan layanan masyarakat atau ILM memiliki tugas yang lebih rumit, yakni membujuk khalayak sasaran untuk mau mengubah perilaku. Dari perilaku yang sebelumnya tidak atau kurang baik, menjadi perilaku yang positif seperti yang diinginkan oleh komunikator. Dalam tataran ini, ILM dituntut untuk menjalankan fungsinya sebagai sebuah bentuk komunikasi persuasif.

Mengingat khalayak sasaran memiliki keyakinan, sikap, nilai, dan kebutuhan yang berbeda (Venus, 2004: 98108), maka desain pesan dalam ILM harus dibuat sedemikian rupa sehingga mampu mengakomodasi berbagai aspek dalam diri khalayak sasaran tersebut. Harapannya, tingkat resistensi khalayak sasaran terhadap pesan iklan dalam ILM dapat diperkecil atau diminimalkan. Hal ini karena sikap dan keyakinan diri, serta lingkungan sekitar biasanya memberikan pengaruh terhadap perilaku seseorang.

Salah satu isu penting yang sering kali dianggap mendesak untuk disampaikan kepada masyarakat adalah berkaitan dengan masalah kesehatan. Demikian penting dan luasnya masalah kesehatan ini sehingga 
Kementerian Kesehatan RI secara teratur menayangkan ILM di televisi untuk mengedukasi dan mempersuasi masyarakat. Tema kesehatan yang diangkat dalam ILM cukup beragam, mulai dari edukasi tentang pencegahan penyakit kanker, ajakan untuk pentingnya melakukan imunisasi pada anak-anak, hingga ajakan untuk berhenti merokok yang sangat berbahaya bagi kesehatan.

Berkaitan dengan edukasi mengenai kanker, pemerintah perlu untuk memberikan perhatian secara lebih serius dikarenakan kian meningkatnya jumlah penderita kanker di Indonesia. Berdasarkan data Kementerian Kesehatan (Kemenkes) pada 2012 menyebutkan, prevalensi kanker mencapai 4,3 banding 1.000 orang. Padahal data sebelumnya menyebutkan prevalensinya 1 banding 1.000 orang. Badan Kesehatan Dunia (WHO) dan Serikat Pengendalian Kanker Internasional (UICC) memprediksi, akan terjadi peningkatan lonjakan penderita kanker sebesar 300\% di seluruh dunia pada 2030. Dari jumlah tersebut, $70 \%$ berada di negara berkembang seperti Indonesia. Bahkan di beberapa daerah prevalensi tersebut lebih tinggi, seperti 7,4 per 1.000 penduduk di Jakarta, 8,1 per 1,000 di Jawa Tengah, dan 9,6 per 1.000 penduduk di DI Yogyakarta.
Angka kematian oleh kanker cenderung meningkat. Pada 1984 kanker masih menempati urutan ke-6 penyebab kematian di Indonesia, namun saat ini telah bergeser ke urutan ke-5. Hal tersebut diperkirakan akan terus meningkat sesuai dengan penambahan angka kejadian kanker bila tidak dilakukan promosi seperti melakukan deteksi dini pada masyarakat.

Penderita kanker rata-rata datang berobat dalam kondisi stadium menengah atau bahkan akhir sehingga pengobatannya menjadi lebih kompleks dan memakan biaya yang tidak sedikit. Padahal, apabila deteksi kanker dilakukan sejak dini, peluang kesembuhan pasien akan jauh lebih tinggi dan biaya pengobatan yang dikeluarkan juga tidak terlalu besar. Penyakit kanker sebenarnya bisa dihindari dengan pola hidup sehat yang terdiri dari pola makan sehat, olahraga, dan istirahat cukup. Pola hidup sehat ini jika diterapkan dengan sungguh-sungguh bisa mengeliminasi penyakit kanker.

Umumnya, masyarakat belum terlalu peduli untuk menjaga kesehatan, hingga akhirnya terdeteksi kanker. Diperlukan upaya yang terus-menerus dan konsisten untuk menyadarkan masyarakat agar peduli pada penyakit kanker. Dalam hal ini, Kementerian Kesehatan RI selain membentuk Komite Penanggulangan 
Kanker Nasional (KPKN) untuk menanggulangi dan memecahkan berbagai masalah terkait kanker.

Kementerian Kesehatan juga melakukan edukasi cara pencegahan penyakit kanker, baik melalui penerapan pola hidup sehat maupun dengan deteksi dini kanker. Edukasi tersebut salah satunya dilakukan melalui komunikasi persuasif dalam bentuk ILM. Sayangnya, mengajak masyarakat yang menjadi target audience ILM untuk mengubah perilaku ke arah positif bukanlah hal yang sederhana. Sering kali komunikator tidak memahami apa yang ada di benak target audience serta hambatan apa yang menghalangi mereka untuk melakukan sebuah perubahan.

Tidak hanya elemen pesan, endorser yang memiliki peran cukup vital sebagai penyampai pesan juga tidak dipilih secara tepat. Hal ini dapat dilihat dari banyaknya ILM yang di-endorse oleh para pejabat atau petinggi departemen terkait. Jika pejabat tersebut memang seorang tokoh yang cukup "didengar" oleh target audience, maka seperti yang diungkapkan Kotler dan Lee di atas, ILM akan lebih mudah memersuasi masyarakat. Namun jika sebaliknya, komunikasi persuasif dalam ILM tersebut belum dapat terwujud. Jangankan mengubah perilaku, mengingat pesan yang disampaikan saja terkadang target audience tidak mampu karena pengemasan pesan yang kurang jelas, terlalu bertele-tele penyampaiannya, bahkan terlalu cepat sehingga sulit dicerna.

ILM bertema kesehatan, terutama terkait dengan edukasi tentang kanker menarik untuk dikaji mengingat pencegahan penyakit kanker merupakan masalah yang kompleks dan membutuhkan tanggung jawab bersama antara pemerintah dan seluruh elemen masyarakat. ILM merupakan salah satu alat untuk menggerakkan masyarakat agar bersedia mengubah perilaku ke arah yang positif dalam hal kesehatan. Sesuai misi Departemen Kesehatan, untuk meningkatkan derajat kesehatan masyarakat melalui pemberdayaan masyarakat termasuk swasta dan masyarakat madani, komunikasi persuasif melalui ILM seharusnya mampu menjaring partisipasi masyarakat agar mereka turut andil melakukan pola hidup sehat.

Karena itulah tim pengusul memandang perlu diteliti sebuah komunikasi persuasif yang dapat diterapkan pada ILM bertema kesehatan khususnya ILM kesadaran tentang kanker. Temuan dari penelitian ini diharapkan dapat menjadi pijakan dalam menciptakan ILM kesadaran tentang kanker yang mampu menggerakkan masyarakat untuk mendukung perubahan 
perilaku ke arah positif, yakni peduli pada penyakit kanker dan kemudian bersedia melakukan tindakan (action) agar terhindar dari kanker. Harapannya, jika masyarakat semakin peduli dengan kanker maka kesadaran untuk melakukan pola hidup sehat dan deteksi dini kanker juga meningkat sehingga mampu menurunkan angka penderita kanker di Indonesia. Berdasarkan latar belakang penelitian yang telah dipaparkan, maka rumusan masalah dalam penelitian ini adalah: "Bagaimanakah komunikasi persuasif iklan layanan masyarakat di televisi untuk meningkatkan kesadaran tentang kanker yang mampu mendukung perubahan perilaku?"

Adapun tujuan khusus penelitian adalah sebagai berikut: 1) Mengidentifikasi perilaku khalayak sasaran terhadap ILM edukasi kanker dari Kementerian Kesehatan; 2) Menganalisis faktor-faktor yang mempengaruhi khalayak sasaran untuk mengubah perilaku setelah melihat tayangan ILM bertema kesehatan dari Kementerian Kesehatan, 3) Menguraikan komunikasi persuasif untuk menciptakan tentang edukasi kanker yang mampu mendukung perubahan perilaku masyarakat ke arah positif.

Manfaat teoritis, yaitu hasil penelitian ini dapat memberikan kontribusi bagi pengembangan ilmu komunikasi khususnya berkaitan dengan teori komunikasi persuasif dan Iklan Layanan Masyarakat (ILM) sebagai bagian dari kampanye pemasaran sosial (social marketing). Sedangkan manfaat praktis, hasil penelitian ini dapat diaplikasikan untuk melihat komunikasi persuasif yang bisa menjadi pijakan saat akan membuat ILM edukasi kanker yang mampu mendukung perubahan perilaku masyarakat agar lebih peduli terhadap penyakit kanker dan mau melakukan pola hidup sehat agar terhindar dari penyakit kanker.

\section{TINJAUAN LITERATUR}

\section{Komunikasi Persuasif}

KomunikasiPersuasif diperlukan
untuk menggerakkan orang agar mau
mengubah perilaku mereka sesuai dengan
yang diinginkan oleh komunikator. Simon
(1976) dalam Dainton dan Zelley (2004:
104) mendefinisikan persuasi sebagai
berikut: Persuasionis typically defined as
"human communication that is designed to
influence others by modifying their beliefs,
values, or attitudes"
Terdapat empat Teori Persuasi
yakni: Social Judgment Theory,
Elaboration likelihood model, Cognitive
Dissonance Theory, dan Narrative
Paradigm. Dua teori pertama, Social


Judgment Theory dan Elaboration likelihood model beranggapan bahwa komunikator yang akan melakukan komunikasi persuasif harus mempertimbangkan target audience sebelum menyusun pesan. Berikut adalah penjelasan singkat dari keempat teori tersebut:

\section{Social Judgment Theory}

Menurut teori ini sikap target audience saat ini merupakan hal yang penting karena mengirimkan pesan yang jatuh pada area penolakan (latitude of rejection) dari si penerima tidak akan menghasilkan persuasi yang sukses. Persuasi yang sebenarnya atau "true persuasion" hanya akan terjadi ketika pesan persuasif berada dalam area non commitment (latitude of non commitment) dari si penerima (yang berarti si penerima pesan belum memiliki preferensi apapun) atau berada dalam area penerimaan (latitude of acceptance) si penerima pesan.

\section{Elaboration likelihood model}

Teori ini juga menekankan pentingnya mengetahui target audience. Dalam kasus ini, penerima pesan harus termotivasi dan mampu mengolah pesan secara objektif dan rinci. Ketika target audience tidak termotivasi atau tidak dapat memproses pesan (atau keduanya), isyarat dari sekeliling harus digunakan.

\section{Cognitive Dissonance Theory}

Teori ini menjelaskan persuasi sebagai respons postreactive dari keyakinan dan tindakan yang inkonsisten. Individu lebih memilih untuk menjaga konsistensi antara keyakinan dan perilaku. Komunikator dapat mengambil keuntungan dari ketidaksesuaian penerima pesan dengan mengusulkan solusi, produk, atau tindakan yang mencoba untuk menutup kesenjangan antara keyakinan yang kongruen dengan perilaku.

\section{Narrative Paradigm}

Merupakan pandangan paradigma narasi persuasi melalui lensa deskriptif. Artinya, persuasi tidak memiliki banyak proses rasional, sebagaimana proses emosional yang berpijak pada storytelling. Yang penting, narasi harus memiliki kecocokan dan logika alasan yang baik agar mampu mempengaruhi target audience. (Dainton dan Zelley, 2004: 104-12).

\section{Landasan Konsep Komunikasi Persuasif Ketika melakukan persuasi, perhatian kita dapat terpusat pada upaya mengubah atau memperkuat sikap atau kepercayaan sasaran persuasi, atau pada upaya mengajak}


mereka untuk bertindak dengan cara tertentu. Dari penjelasan tersebut, terdapat tiga konsep yang perlu kita uraikan yaitu:

\section{Sikap}

Sikap adalah
kecenderungan untuk berperilaku
dengan cara tertentu. Melalui
komunikasi persuasif, seorang receiver
(penerima pesan) dapat berubah sikap
karena paparan informasi dari sender
(pengirim pesan). Menurut Martin
Fishbein, sikap adalah suatu
kecenderungan untuk memberi reaksi
yang menyenangkan,
menyenangkan, atau netral terhadap
suatu objek atau sebuah kumpulan
objek. Sasaran perubahan sikap
tersebut meliputi aspek dasar sikap
manusia yaitu aspek afektif (kesukaan
atau perasaan terhadap suatu objek),
kognitif (keyakinan terhadap sebuah
objek), dan motorik / perilaku
(tindakan terhadap objek) dengan
uraian sebagai berikut:

a. Sasaran aspek kognitif dalam

komunikasi persuasif

Dalam proses ini, pesan yang berkaitan dengan objek sikap disampaikan kepada individu, agar ia bersedia menyetujui ide-ide yang termuat dalam pesan tersebut. Proses kognitif berjalan saat proses persuasif terjadi, sampai akhirnya individu memutuskan setuju atau tidak setuju terhadap objek sikap.

b. Sasaran aspek afektif dalam komunikasi persuasif

Pada bagian ini proses afektif atau emosi yang akan dijadikan pokok bahasan. Ketika pesan persuasi disampaikan, pesan tersebut akan menyentuh dan mempengaruhi aspek emosi individu yang dijadikan sasaran persuasi. Pavlov dalam prinsip classical atau respondent conditioning mengemukakan bahwa seseorang akan bersikap positif terhadap objek yang sering disajikan bersamaan dengan stimulus positif, begitu pun sebaliknya, seseorang akan bersikap negatif terhadap objek yang disajikan bersamaan dengan stimulus negatif. Prinsip tersebut berkaitan dengan proses afektif seseorang ketika menerima pesan.

c. Sasaran aspek motorik/perilaku dalam komunikasi persuasif

Tensi disonansi memotivasi kita untuk berubah, baik perilaku kita atau keyakinan kita dalam upaya untuk menghindari perasaan tertekan. Semakin penting isu (pesan) untuk kita dan semakin 
besar perbedaan di antara perilaku dan keyakinan kita, maka semakin tinggi besarnya disonansi yang akan kita rasakan. Perubahan sikap dapat terjadi karena adanya keinginan seseorang untuk menghilangkan keadaan

ketidakcocokan/ketidaknyamanan.

\section{Kepercayaan}

Kepercayaan adalah rasa yakin akan adanya sesuatu atau akan kebenaran sesuatu. Kepercayaan timbul akibat dari percampuran observasi pengalaman, bukti dari pihak kedua, juga motivasi yang kompleks. Martin Fishbein mengatakan bahwa kepercayaan adalah hipotesis bahwa suatu objek itu ada dan bahwa hubungan yang terjadi di antara objek dengan pertimbangan objek-objek yang lainnya. Sehingga menurut definisi tersebut, terdapat dua kepercayaan yaitu kepercayaan kepada objek dan kepercayaan tentang objek. Kepercayaan kepada objek seperti Fulan sedang mengalami cedera. Kepercayaan tentang objek seperti cedera yang dialami Fulan tidak akan berlangsung lama.

\section{Perilaku}

Perilaku dalam persuasi mengacu pada tindakan yang jelas atau dapat diamati. Perilaku merupakan tindakan dari sikap kita terhadap sesuatu. Seperti perilaku membuang sampah pada tempatnya merupakan salah satu tindakan yang terlihat dari orang yang memiliki sikap sadar akan kebersihan.

\section{Iklan Layanan Masyarakat}

Iklan layanan masyarakat (ILM) merupakan proses penyampaian informasi yang bersifat persuasif atau mendidik khalayak melalui media periklanan agar pengetahuannya bertambah, menumbuhkan kesadaran sikap dan perubahan perilaku masyarakat terhadap masalah yang disampaikan, serta mendapatkan citra yang baik di benak masyarakat (Pujiyanto, 2013: 11).

Sementara itu, menurut Lee dan Johnson (2004: 9) ILM atau dalam bahasa inggris dikenal sebagai public service advertising (PSA) adalah jenis periklanan yang dilakukan oleh suatu organisasi komersial maupun non-komersial (pemerintah) untuk mencapai tujuan sosial atau sosio-ekonomis. "Periklanan pelayanan masyarakat dirancang untuk beroperasi untuk kepentingan masyarakat dan mempromosikan kesejahteraan masyarakat". Bila ditinjau dari proses komunikasi, tugas ILM adalah: (1) untuk menimbulkan kesadaran masyarakat, (2) 
memberi pemahaman informasi agar masyarakat yang belum menyukai atau tidak menyukai dapat dirayu untuk mempelajarinya, (3) langkah keyakinan atau sikap, yaitu bagaimana agar masyarakat memiliki niat untuk membaca atau melihat, (4) tahap tindakan, kadang masyarakat sudah terbiasa dengan pesan yang diinformasikan pada media tertentu, lain halnya ILM yang tampilannya beda, hingga akhirnya mengadakan tindakan atau langkah baru untuk mengikuti apa yang diinformasikan (Pujiyanto, 2013: 93-94).

\section{METODOLOGI PENELITIAN}

Pendekatan penelitian ini menggunakan metode studi kasus melalui pendekatan deskriptif kualitatif. Deskriptif kualitatif merupakan metode yang digunakan untuk membedah suatu fenomena di lapangan. Penelitian deskriptif kualitatif adalah metode yang menggambarkan dan menjabarkan temuan di lapangan.

Metode deskriptif kualitatif hanyalah memaparkan situasi atau peristiwa. Penelitian dengan metode ini tidak mencari atau menjelaskan hubungan, tidak menguji hipotesis atau membuat prediksi. Penelitian deskriptif ditujukan untuk mengumpulkan informasi secara aktual dan terperinci, mengidentifikasikan masalah, membuat perbandingan atau evaluasi, dan menentukan apa yang dilakukan orang lain dalam menghadapi masalah yang sama juga belajar dari pengalaman mereka untuk menetapkan rencana dan keputusan pada waktu yang akan datang.

Objek yang diteliti adalah ILM Departemen Kesehatan RI yang ditayangkan pada 2015, yakni ILM tentang Edukasi Kanker. Terdapat tiga versi yang diteliti, yakni versi Pemeriksaan Inspeksi Visual Asam Asetat durasi 30 detik, versi Animasi Cara Cegah Kanker dengan Cerdik. durasi 30 detik, dan versi Animasi Cara Cegah Kanker dengan Cerdik durasi 60 detik. Versi Pemeriksaan Inspeksi Visual Asam Asetat diambil karena menggunakan pendekatan endorser tenaga kesehatan dan ibu-ibu anggota Organisasi Aksi Solidaritas Era Kabinet Kerja. Versi ini dibandingkan dengan versi animasi, untuk mengetahui manakah yang lebih menarik bagi khalayak sasaran untuk mendukung perubahan perilaku terkait dengan kesadaran akan penyakit kanker. Selain itu juga akan diteliti dari sisi durasi, manakah yang lebih mudah diingat khalayak sasaran, ILM berdurasi 30 detik atau 60 detik. Penelitian dilakukan pada 2017 di Universitas Muhammadiyah Jakarta, Cirendeu, Ciputat. 
HASIL PENELITIAN DAN

PEMBAHASAN

\section{Identifikasi Perilaku Khalayak Sasaran Terhadap ILM}

Guna memperoleh dan mengumpulkan data, dilakukan focus group discussion (FGD) yang dilaksanakan pada Sabtu, 29 Juli 2017 di Gedung FISIP Universitas Muhammadiyah Jakarta. Peserta FGD terdiri dari sembilan orang mahasiswa semester akhir yang dipilih secara purposive untuk menjadi informan. Terdapat tiga versi ILM tentang edukasi kanker yang diputarkan dalam FGD tersebut secara berurutan, yakni ILM versi Pemeriksaan Inspeksi Visual Asam Asetat durasi 30 detik, versi Animasi Cara Cegah Kanker dengan Cerdik durasi 30 detik, dan versi Animasi Cara Cegah Kanker dengan Cerdik durasi 60 detik.

Versi pertama yang diputarkan yakni Pemeriksaan Inspeksi Visual Asam Asetat diambil karena menggunakan pendekatan endorser tenaga kesehatan dan ibu-ibu anggota Organisasi Aksi Solidaritas Era Kabinet Kerja. Versi ini menggunakan pendekatan slice of life yang diawali dengan pemaparan bahaya kanker leher rahim oleh seorang tenaga kesehatan wanita. Adegan berikutnya menceritakan seorang tukang ojek yang mengajak penumpang wanitanya untuk melakukan pemeriksaan IVA, dan menceritakan bahwa istrinya sudah melakukan pemeriksaan IVA. Iklan ditutup dengan ibu-ibu anggota Organisasi Aksi Solidaritas Era Kabinet Kerja yang bersama-sama menyerukan kepada pemirsa untuk cek IVA sekarang juga.

Berdasarkan hasil FGD, perilaku khalayak sasaran terhadap ILM versi pertama rata-rata menganggap ILM tersebut cukup informatif, namun kurang detil. Informatif yang dimaksud di sini adalah cukup bisa memberikan informasi kepada mereka bahwa saat ini untuk pencegahan kanker leher rahim dapat dilakukan melalui deteksi dini IVA. Sedangkan ILM dianggap kurang detil karena tidak adanya gambaran secara spesifik tentang IVA. Iklan juga dianggap cocok untuk edukasi, dianggap mampu memberikan informasi namun tidak secara terperinci. Alur cerita dianggap sudah baik namun durasinya terlalu pendek untuk dapat memuat semua pesan yang ingin disampaikan.

Meskipun dianggap cukup informatif, namun ILM ini dianggap oleh informan masih memiliki kelemahan, yakni videonya kurang menarik. Endorser tenaga kesehatan yang muncul di awal tidak terlalu diingat karena pesannya terlalu singkat. Namun kalimat yang diucapkan oleh tenaga kesehatan yakni, "Kanker leher rahim 
menyebabkan satu perempuan Indonesia meninggal setiap satu jam" cukup membuat beberapa informan mengingat pesan tersebut karena merasa takut akan bahaya kanker leher rahim.

Dari sudut pandang endorser, beberapa informan beranggapan tukang ojek dianggap sebagai endorser yang paling menarik. Hal ini menyiratkan bahwa informan lebih menyukai endorser yang dianggap dekat dan akrab dengan keseharian mereka. Meskipun mereka juga menyatakan bahwa dokter dan tenaga medis merupakan endorser yang trustable atau dapat dipercaya untuk menerangkan sesuatu hal yang berkaitan dengan dunia medis. Sedangkan ibu-ibu pejabat sebagai endorser yang berada di akhir iklan tidak disukai karena dianggap tidak relevan. Selain itu, running text yang berada di bawah iklan dan muncul sejak awal hingga akhir iklan dianggap mengganggu dan memecah konsentrasi informan untuk mencerna pesan yang disampaikan oleh endorser.

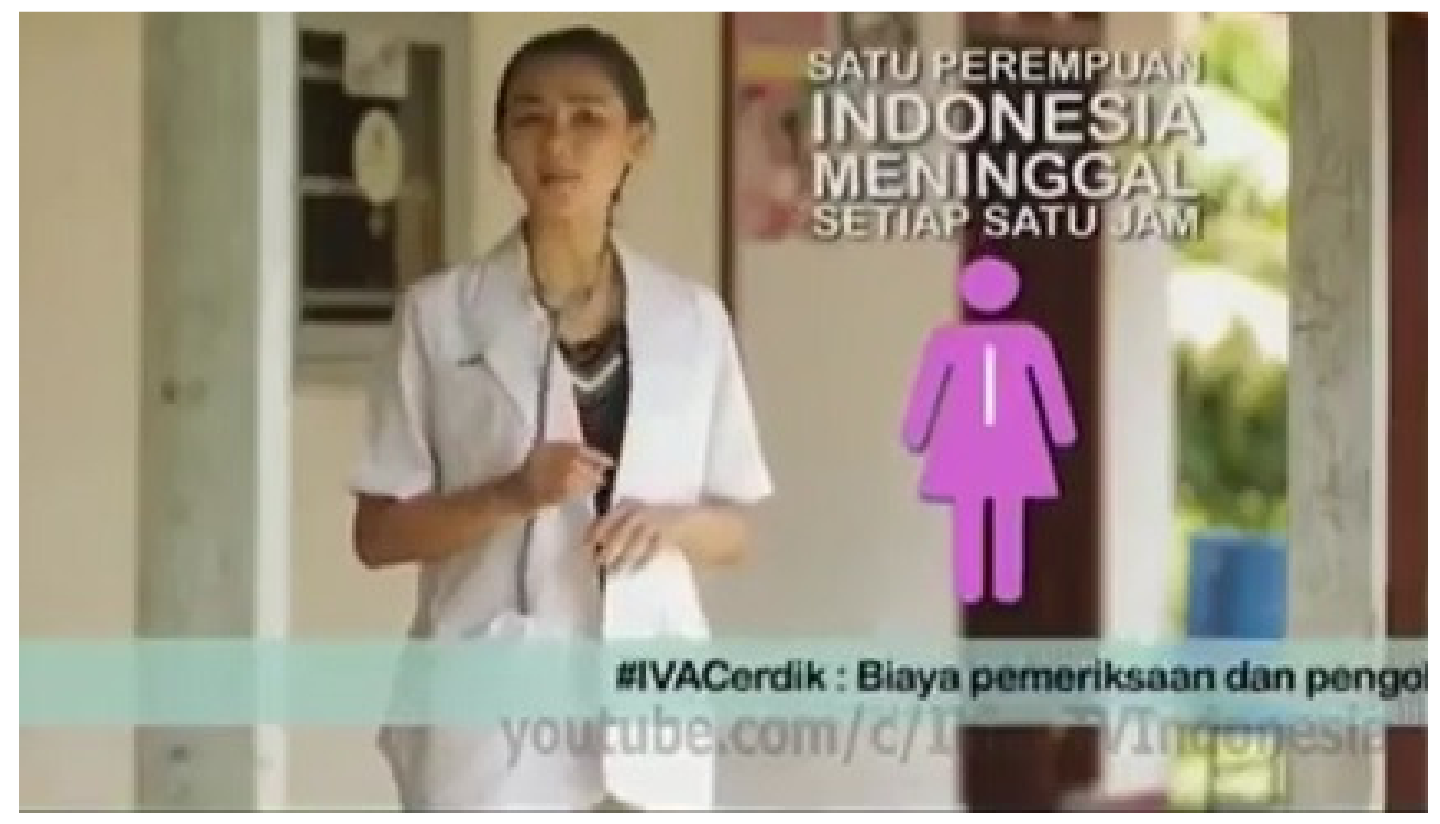

Gambar 1. Tenaga kesehatan sebagai endorser pada ILM versi Pemeriksaan Inspeksi Visual Asam Asetat 


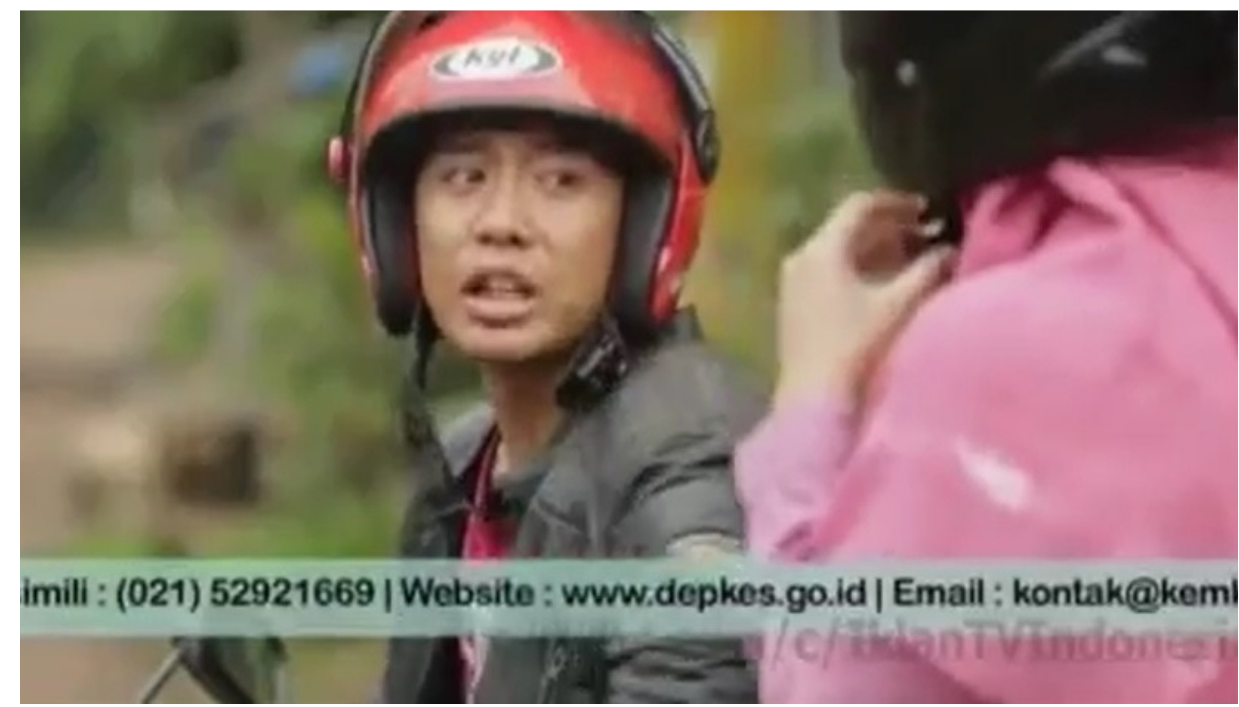

Gambar 2. Tukang ojek sebagai endorser pada ILM versi Pemeriksaan Inspeksi Visual Asam Asetat

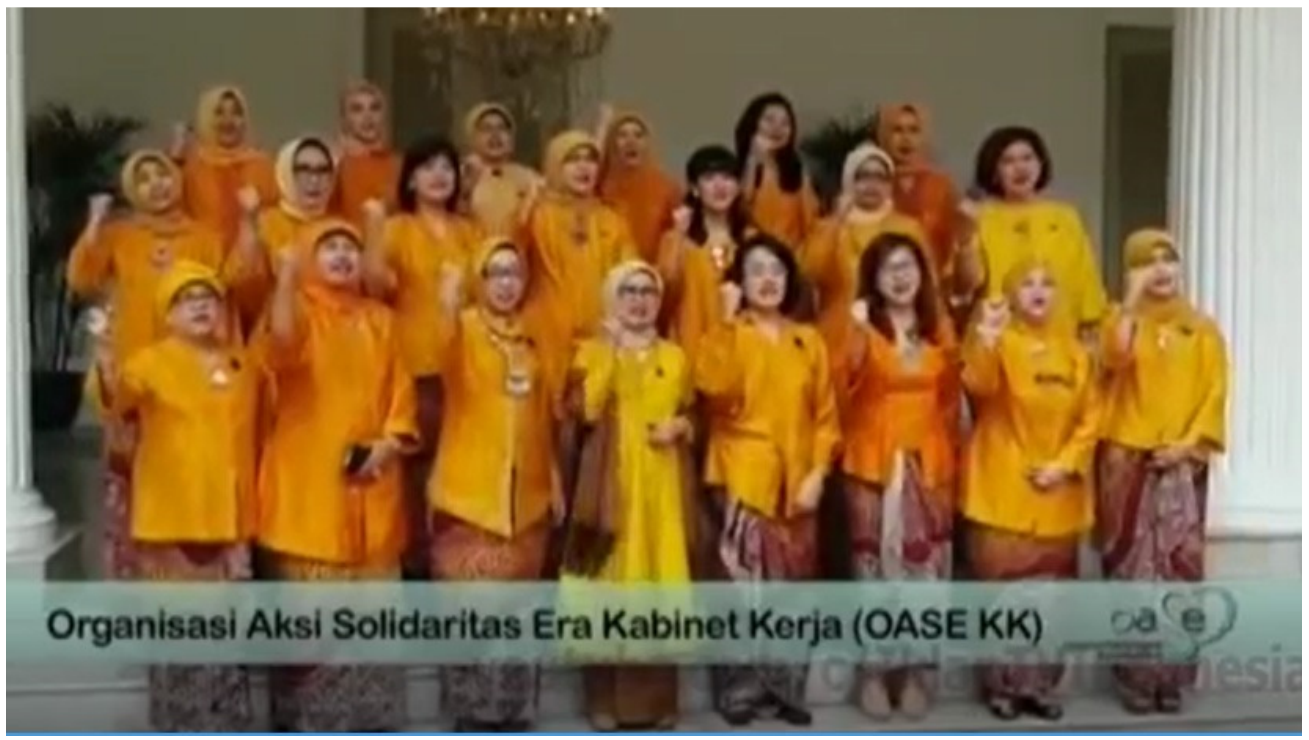

Gambar 3. Ibu-ibu dari Organisasi Aksi Solidaritas Era Kabinet Kerja sebagai endorser

Untuk mengetahui manakah yang lebih menarik bagi khalayak sasaran untuk mendukung perubahan perilaku terkait dengan kesadaran akan penyakit kanker, versi ini akan dibandingkan dengan versi animasi,. Selain itu juga akan diteliti dari sisi durasi, manakah yang lebih mudah diingat khalayak sasaran, ILM berdurasi 30 detik atau 60 detik.

Pada pemutaran ILM kedua, informan menyaksikan ILM versi Animasi Cara Cegah Kanker dengan Cerdik durasi 30 
detik. Setelah iklan kedua diputar, rata-rata informan menyatakan bahwa ILM dengan pendekatan animasi tersebut cukup menarik karena pesan dapat dipahami serta mudah diingat. Berikut pernyataan dari salah satu informan.

"Ringkas, menarik, dan jelas.

Tidak seram gambarnya, lebih ke control management, solusi yang langsung untuk pencegahan. Sekali lihat kita langsung ingat dan lebih menarik yang ini, lebih detil aja.”

Selain itu, iklan kedua juga dianggap mampu memberikan solusi untuk pencegahan penyakit kanker serta tampilan iklan yang energik dan semangat melalui tokoh Kancil sebagai endorser mampu membuat iklan ini terlihat menarik di mata para informan.

“Lebih menarik (yang kedua) karena rasa takutnya jadi kurang, tetapi bukan berarti kita tidak mau untuk pencegahan. Ketakutan pasti ada tetapi kita sudah dikasih solusi untuk pencegahan. Walaupun singkat, iklan kedua ini mudah dipahami dan model iklan ini lebih energik, semangat, jadi seperti ngasih pencegahan dari virus."

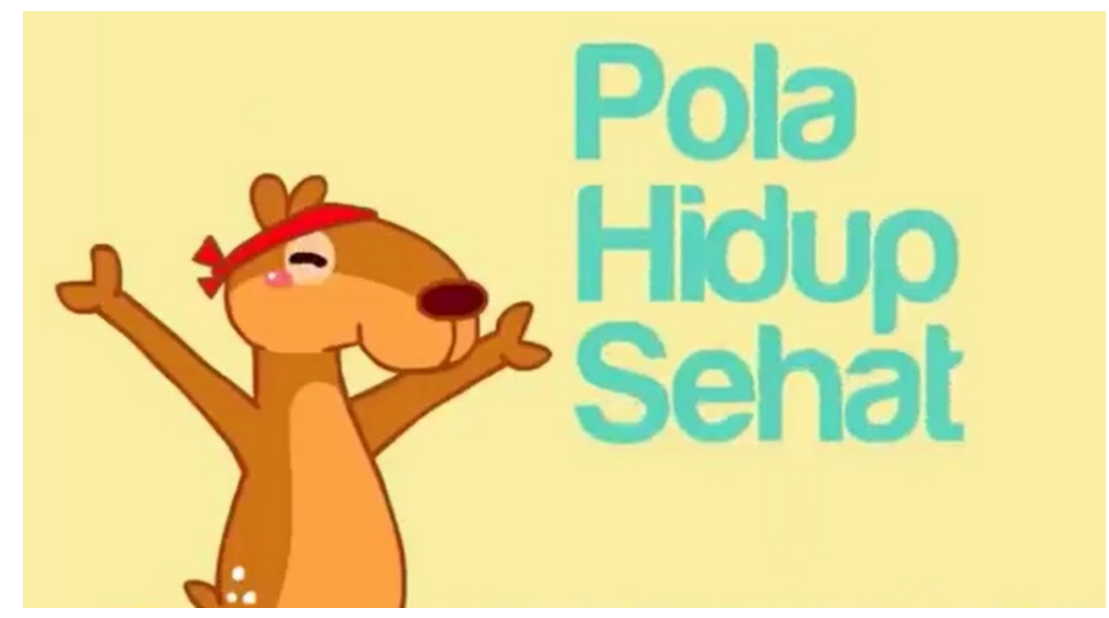




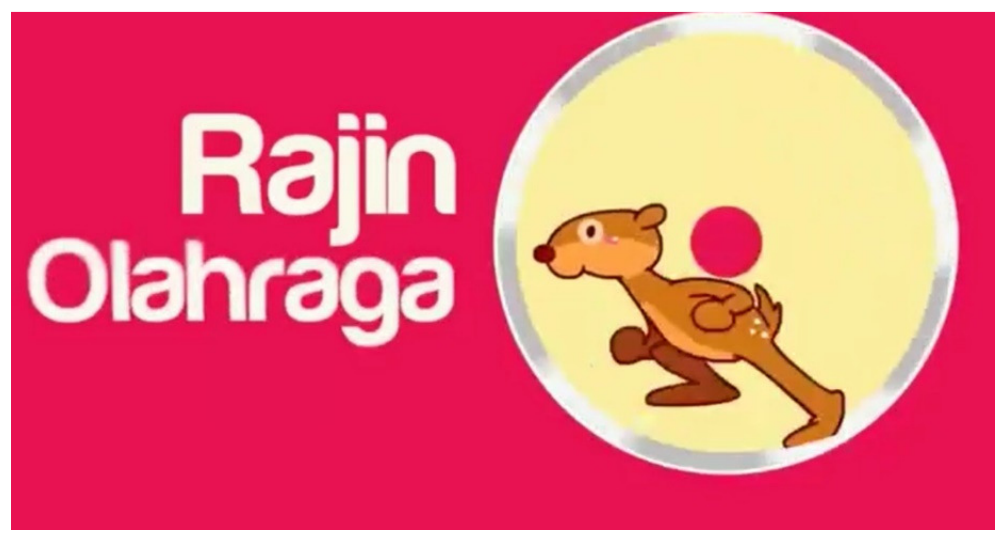

Gambar 4 dan 5. ILM versi Animasi Cara Cegah Kanker dengan Cerdik

Kemudian ketika ditanyakan apakah iklan animasi ini cocok untuk edukasi penyakit kanker, rata-rata informan menjawab cocok.

"Iya cocok banget. Karena solusi, pesannya dapet, kalau dari segi tampilan, ya lucu, lebih menarik, dan tidak bikin stres."

Kancil sebagai endorser juga dianggap mampu mewakili pesan iklan yang ingin disampaikan, yakni cegah kanker dengan pola hidup sehat yang disingkat dengan “CERDIK” yakni: 1) cek rutin kesehatan 2) enyahkan asap rokok 3) rajin olahraga 4) diet seimbang 5) istirahat cukup 6) kelola stres. Berikut adalah petikan pendapat informan:

"Saya juga tidak tahu kancil itu ngapain, tapi pas di terakhirnya dikasih tahu 'cerdik' baru sadar kancil itu kan cerdik.”

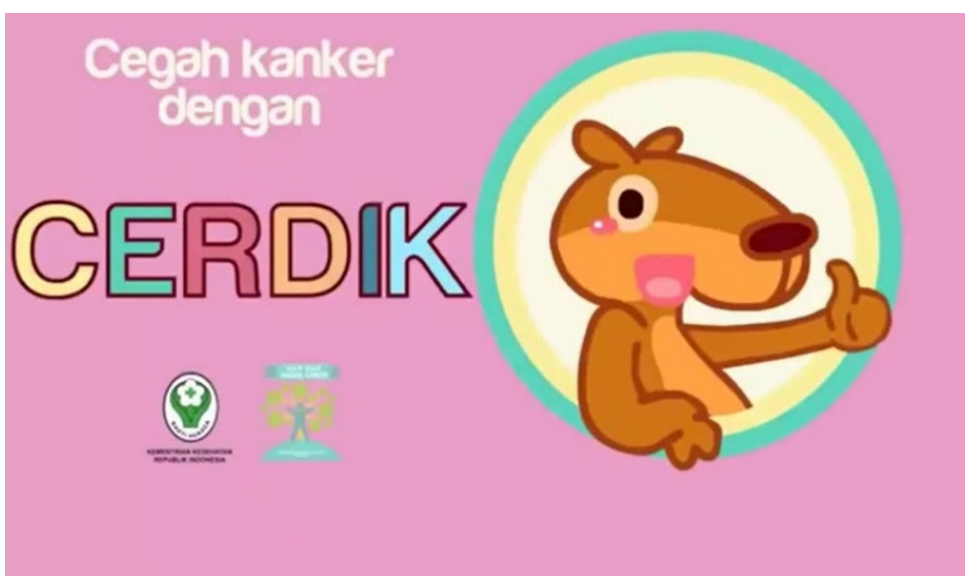

Gambar 6. Kancil sebagai endorser mampu merepresentasikan kata "CERDIK" yang digunakan sebagai akronim cara pencegahan kanker 
Faktor-Faktor yang Mempengaruhi Khalayak Sasaran untuk Mengubah Perilaku

\section{Melalui Komunikasi Persuasif}

Setelah melihat ILM versi pertama, informan wanita terpengaruh untuk melakukan pemeriksaan. Pernyataan dari tenaga kesehatan di awal iklan yang menyebutkan bahwa, "Kanker leher rahim menyebabkan satu perempuan Indonesia meninggal setiap satu jam" membuat informan memiliki ketakutan terhadap kanker leher rahim dan berpikiran untuk melakukan deteksi dini melalui pemeriksaan IVA. Hal ini seperti yang diungkapkan oleh informan melalui pernyataannya sebagai berikut:

"Kalau secara persuasif sih informatif, langsung kepikiran karena iklan tersebut menekankan lebih ke ketakutan kita sebagai perempuan dengan kata-kata di setiap satu jam ada yang terkena kanker rahim dan meninggal. Selama ini tahunya udah ramai dan ada teman yang mengalami itu.”

Selain slice of life, pendekatan fear arousing atau pemunculan rasa takut melalui pemaparan fakta bahwa satu orang perempuan di Indonesia tiap jam meninggal karena kanker leher rahim ternyata cukup berhasil memersuasi khalayak sasaran untuk melakukan pencegahan kanker melalui deteksi dini. Para informan wanita mengaku bahwa mereka ketakutan setelah melihat bagian awal dari iklan ini.

"Saya terdorong memeriksa dan ada ketakutan. Saya rasa setiap wanita memiliki

ketakutan seperti saya setelah melihat iklan ini."

Sedangkan informan pria terdorong untuk memberikan informasi kepada kerabat terdekat untuk melakukan deteksi dini kanker rahim melalui pemeriksaan. Seorang informan pria menuturkan bahwa ia terdorong untuk memberikan informasi tersebut kepada istrinya.

“Kita terdorong untuk memberikan informasi. Sebelum saya lihat iklan ini juga saya ada planning ke istri untuk periksa, pencegahan dini, dan adanya iklan ini ada tambahan (semakin menguatkan -red) untuk diperiksa dan saya sadar akan adanya penyakit ini. Istri juga kan sudah pernah 
melahirkan dan memang harus diperiksa lagi.”

Salah satu informan pria bahkan terpikir tentang para PSK yang minim informasi tentang pencegahan kanker leher rahim ini melalui deteksi dini. Menurutnya, para PSK tersebut juga rentan terkena kanker leher rahim dan selayaknya mendapatkan informasi yang lebih banyak mengenai deteksi dini kanker leher rahim. Hal ini terungkap dari pernyataan berikut:

"Mungkin kalau saya kan tinggal di Jakarta Barat, istilahnya banyak banget PSK tiap minggu. Suka ada sosialisasi, penyuluhan, tetapi hanya ada tempelan poster saja. Pencegahan mereka tidak ada sama sekali. Mereka mikirnya terkena kanker serviks lalu meninggal dan tidak sampai periksa ke dokter."

Komunikasi Persuasif Iklan Layanan Masyarakat untuk Meningkatkan Kesadaran tentang Kanker yang Mampu Mendukung Perubahan Perilaku Masyarakat ke Arah Positif

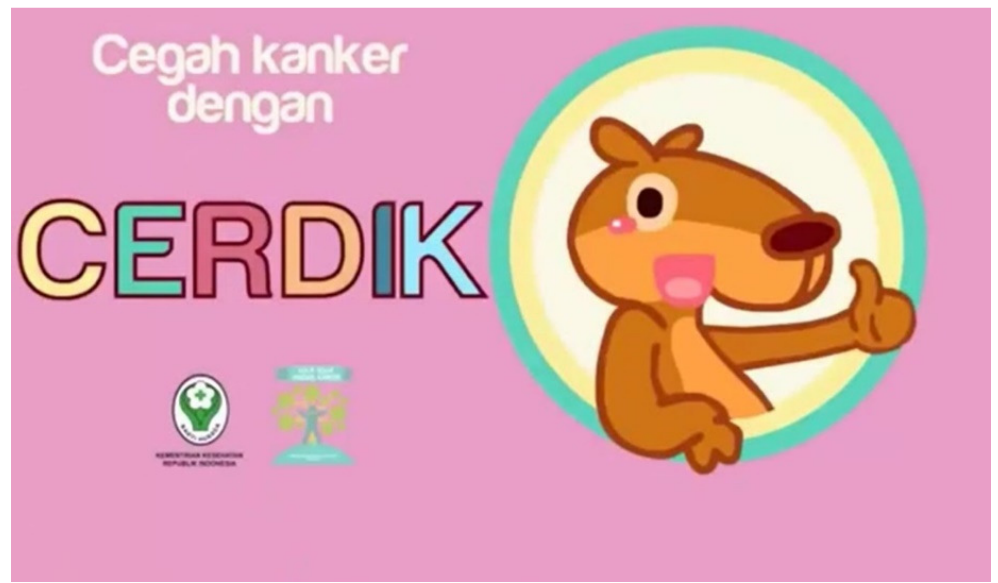

Gambar 7. ILM versi Animasi Cara Cegah Kanker dengan Cerdik

Pada iklan layanan masyarakat versi kancil sangat jelas terlihat adanya anjuran untuk mengubah pola hidup sehat seperti yang terlihat dari tagline yang muncul pada iklan tersebut: "CERDIK", yang memiliki makna tertentu. Hal tersebut diharapkan dapat menjadi tips pencegahan masyarakat akan bahaya dari penyakit kanker. 
Terdapat landasan konsep persuasif dantaranya adalah melalui komunikasi persuasif pada iklan tersebut diharapkan dapat mengubah sikap karena paparan isi pesan.

Sasaran aspek kognitif dalam komunikasi persuasif. Dalam iklan tersebut pesan yang berkaitan dengan objek sikap disampaikan kepada khalayak, agar ia bersedia menyetujui ide-ide atau anjuran yang termuat dalam pesan pada iklan layanan masyarakat tersebut. Seperti halnya iklan pertama juga memberi reaksi yang menyenangkan karena informasi penting yang diterimanya, tidak menyenangkan karena rasa takut akan fakta yang dimunculkan dalam iklan yang pertama diputarkan bahwa satu perempuan Indonesia meninggal setiap satu jamnya pada iklan pertama.

Kepercayaan muncul karena rasa yakin akan adanya sesuatu atau akan kebenaran sesuatu. Kepercayaan timbul akibat dari percampuran observasi pengalaman, bukti yang ditampilkan. Jika dilihat dari Prinsip partisipasi khalayak pada iklan layanan masyarakat versi Pemeriksaan Inspeksi Visual Asam Asetat.

Khalayak yang dimaksudkan di sini adalah masyarakat. Iklan layanan masyarakat tersebut menampilkan adegan seorang tukang ojek yang mengajak penumpang wanitanya untuk melakukan pemeriksaan IVA. Ia juga menceritakan bahwa istrinya sudah melakukan pemeriksaan IVA. Seolah-olah sebagian masyarakat sudah berperan aktif dalam kegiatan pencegahan tersebut.

\section{SIMPULAN}

Berdasarkan hasil pembahasan dan penelitian maka dapat ditarik beberapa kesimpulan sebagai berikut:

1. Perilaku khalayak sasaran terhadap ILM tersebut menurut informan cukup informatif, namun ada beberapa yang menjadi kelemahan. Pertama, informasi yang kurang detail. Kedua, penyajian videonya yang masih kurang menarik. Informan lebih menyukai endorser yang dianggap dekat dan akrab dengan keseharian mereka seolah dapat mewakili mereka. Informan menganggap iklan animasi ini cocok untuk edukasi penyakit kanker karena pesannya yang jelas dan mudah dimengerti.

2. Faktor-faktor yang mempengaruhi khalayak sasaran untuk melakukan pemeriksaan karena adanya pernyataan dari tenaga kesehatan di awal iklan yang menyebutkan bahwa, "kanker leher rahim menyebabkan satu perempuan Indonesia meninggal setiap 
satu jam" pendekatan fear arousing atau pemunculan rasa takut melalui pemaparan fakta. Sedangkan informan pria terdorong untuk memberikan informasi kepada kerabat terdekat untuk melakukan deteksi dini kanker rahim melalui pemeriksaan. Selain itu, karena adanya informasi yang bersifat persuasif untuk mengubah pola hidup sehat dan pemeriksaan sebagai bentuk pencegahan.

3. Pada komunikasi persuasif iklan layanan masyarakat untuk meningkatkan kesadaran masyarakat tentang kanker, terdapat landasan konsep persuasif. Di antaranya adalah perubahan sikap karena paparan isi pesan yang disampaikan. Dalam iklan tersebut pesan yang berkaitan dengan objek sikap disampaikan kepada khalayak, agar ia bersedia menyetujui ide-ide atau anjuran yang termuat dalam pesan pada iklan layanan masyarakat tersebut.

\section{SARAN}

Berdasarkan hasil dari penelitian dan pembahasan yang telah dikemukakan, berikut ada beberapa saran diharapkan dapat menjadi masukan dan pertimbangan dalam pembuatan iklan layanan masyarakat adalah pesan iklan dapat dibuat semenarik mungkin dengan informasi yang detail agar khalayak dapat menangkap pesan tersebut. Menggunakan endorser yang sesuai dengan target khalayak pesan tersebut, agar khalayak merasa memiliki kedekatan, seolah mewakili mereka. Pendekatan yang sesuai salah satunya pendekatan fear arousing atau pemunculan rasa takut melalui pemaparan fakta cukup mampu menggugah khalayak untuk lebih peduli terkait bahaya penyakit kanker.

\section{DAFTAR PUSTAKA}

Dainton, Marianne \& D Zelley, Elaine. 2004. Applying Communication Theory for Professional Life: A Practical Introduction. California: Sage Publications

Lee, M., \& Johnson, C. 2004. Prinsipprinsip Pokok Periklanan dalam Perspektif Global. Jakarta: Prenada Media.

Lee, Nancy R \& Kotler Philip. 2011. Social Marketing: Influence Behaviors for Good. California: Sage Publications

Moleong, Lexy. 2001. Metodologi Penelitian Kualitatif. Bandung: PT Remaja Rosdakarya.

Mc Nab Mc Nabb, David. 2002. Research Methods in Public Administration \& Nonprofit Management: Quantitative \& Qualitative Approaches. M.E. Sharpe.

Pujiyanto. 2013. Iklan Layanan Masyarakat. Yogyakarta: Penerbit Andi 


\section{Jurnal:}

The Elon Journal of Undergraduate Research in Communications, Vol. 4, No. 1, 2013

Journal of Communication 56 S1-S17, International Communication Association, 2006

Journal of Social Issues, Vol. 56, No. 3, 2000, pp. 527-541

Nanyang Tech University, 2009.Strategic Social Marketing in Canada: Ten Phases to Planning and Implementing Cancer Prevention and Cancer Screening Campaigns oleh Jennifer Allyson Dooley, Sandra C. Jones dan Kendra Desmarias dari, tahun 2009.

\section{Website:}

http://www.depkes.go.id/article/view/1301 0100001/profil-visi-dan-misi.html

http://health.kompas.com/read/2013/03/21/ 19425358/Penderita.Kanker.di.Indonesia. Meningkat

http://inacare.org/overview.html

http://health.kompas.com/read/2013/03/21/ 19425358/Penderita.Kanker.di.Indonesia. Meningkat 